УДК 371, 378

Литвинова Світлана Григорівна, молодший науковий співробітник Інституту інформаційних технологій i засобів навчання НАПН України, м. Київ, е-mail: s_litvinova@i.ua

\title{
ВІРТУАЛЬНІ ПРЕДМЕТНІ СПІЛЬНОТИ ЯК ЗАСІБ ПІДТРИМКИ ПРИРОДНИЧО-МАТЕМАТИЧНОЇ ОСВІТИ
}

\begin{abstract}
Анотація
Стаття присвячена пошуку шляхів підвищення якості шкільної природничоматематичної освіти, які спрямовані на використання віртуальних предметних спільнот і реалізацію завдань, що включають розробку структури предметних спільнот, залучення вчителів-предметників до співпраці у спільнотах, створення інформаційно-методичних, дидактичних та розвивальних матеріалів, забезпечення умов їх використання у школі, здійснення аналізу функціонування спільнот.

У статті розкрито особливості віртуальних предметних спільнот, визначено їх види (стабільна, популярна, активна, база знань), особливості формування і фактори вибору предметної спільноти вчителями-предметниками, визначено основні підходи колаборації над документами (неформальне, формальне редагування і рецензування документів), особливості залучення вчителів-предметників до співпраці у спільнотах.

Ключові слова: віртуальні спільноти, віртуальні предметні спільноти, природничо-математична освіта, мережа, якість шкільної освіти, види спільнот, стабільна віртуальна спільнота, популярна віртуальна спільнота, активна віртуальна спільнота, база знань.

Сучасні засоби комунікації досягли такого рівня розвитку, що здатні на довільну відстань передавати від учителя до учня не тільки зміст, а й емоції, які так необхідні для засвоєння нових знань й умінь. Сам же зміст навчального матеріалу отримує «цифрове обличчя» і вимагає таких форм зберігання, які б давали доступ до нього будь-де і будь-коли. 3 розвитком інформаційно-комунікаційних технологій 3'являються програмні сервіси і нові форми для зберігання й управління даними. Останнім часом багато робиться для того, щоб використати досвід обміну знаннями і
\end{abstract}


залучити учнів, студентів, учителів та викладачів до участі в житті реальних предметних спільнот, де у рамках окремої спільноти усі учасники можуть обмінюватися повідомленнями, текстовими документами, відео- й аудіофайлами, а також знаннями, які вони можуть використати у своїй діяльності.

Актуальність дослідження обумовлена тим, що «Концепція Державної цільової соціальної програми підвищення якості шкільної природничо-математичної освіти на період до 2015 року» визначає фундаментальну природничо-математичну освіту одним з основних факторів розвитку особистості, і потребує оновлення іiі змісту 3 урахуванням суспільних запитів, потреб інноваційного розвитку науки і виробництва, запровадження сучасних методів навчання, поліпшення якості підготовки і видання навчально-методичної літератури, удосконалення механізмів оцінювання результатів навчальної діяльності [5].

Систематичне використання IКT під час навчання предметів природничоматематичного циклу в загальноосвітніх навчальних закладах спонукає вчителів до постійного і систематичного створення власних презентацій до окремих тем уроків, тестів, пошуку відео- й аудіофрагментів дослідів тощо. Виникає проблема збереження навчальних матеріалів їх оцінювання, обміну 3 колегами, використання під час атестації, конкурсів. Виникає потреба у створенні і розвитку динамічних віртуальних предметних спільнот.

Наукові пошуки обумовлені широким використанням мережі Інтернет, як комунікаційного середовища з широким комунікаційним потенціалом. У зарубіжній науковій літературі дослідження віртуальних спільнот мають, в основному, описовий характер і орієнтовані на розв'язання таких завдань: формування визначення поняття «віртуальна спільнота» (Денніс А., Рідінгз К., Уеллман Б., Фігалло К., Хільц С. та ін.), розробку класифікації віртуальних спільнот (Портер К., Долакіа У., Вірнош М., Джонс К., Рафаелі С., Кришнамерти С., Коміто Л., Маркус У., Багоззі Р., Батлер Б., Прііс Дж., Армстронг А. та ін.), визначення структурних властивостей віртуальних спільнот (Фігалло К., Портер К., Джонс К., Кришнамерти С., Бленкард А., Харрісон С. та ін.), педагогічний підхід до вивчення віртуальних спільнот Патаракін Є. Д. Розвиток віртуальних спільнот розкрито у працях науковців таких, як: Биков В. Ю., Голощук Р. О., Жалдак М. І., Задорожна Н. Т., Кухаренко В. М., Малицька І. Д., Морзе Н. В., Осадчий В. В., Раков С. А., Самойленко О. М. (Україна), 
Андрєєв О. О., Патаракін Є. Д., Полат С. С., Хуторський А. В., Чураєва Н. С. (Росія), Віркус С. (Великобританія), Боуден Д. (США) та інші.

Нові можливості, які відкриваються перед навчанням, пов'язані з розвитком цифрової пам'яті. Це не тільки збереження даних, але i наявність сервісів, які полегшують можливість індивідуального і колективного їх використання.

3 розвитком мережі ми переходимо від індивідуального програмного забезпечення до мережевих інформаційних застосунків й управління колективною пам’яттю. Прикладом колективної пам'яті може слугувати Всесвітня глобальна павутина (World Wide Web), у якій усі ресурси зберігаються за універсальними адресами URL (Universal Resources Locator). Цифрова пам’ять не тільки вбудовується в усі об'єкти мережевої культури, але поступово вбирає в себе матеріали архівів, музеїв, бібліотек та дослідних інститутів, зазначає Патаракін Є. Д. [4, с. 18]

Усі ці новітні підходи до цифрової і колективної пам'яті останнім часом реалізуються в різних віртуальних спільнотах, особливо в тих, які формуються i підтримуються освітянами.

Втіленням інформаційної епохи нині стала глобальна мережа Інтернет, як ключова інформаційна технологія й універсальний засіб вільної комунікації в освіті. Досягнення у сфері інформаційно-комунікаційних технологій $\epsilon$ підгрунтям для створення нової форми педагогічної комунікації, яка отримала назву віртуальних предметних спільнот.

Важливим фактором у дослідженні віртуальних предметних спільнот $\epsilon$ формування основних понять. Переклад англійських аналогів virtual community, online community, online group узагальнено в понятті «віртуальна спільнота».

Спільнота - мала група або велика соціальна група людей, які активно спілкуються між собою як на професійні, так і на непрофесійні теми [4, с. 22-23].

Спільнота - це група людей, які мають спільні інтереси, прагнення та цілі [8].

Спільнота - це група людей, які взаємодіють між собою, живуть у деякій близькості (просторі, часі, відносинах) [1].

Віртуальна спільнота - соціальне об'єднання, яке виростає з мережі, коли група людей підтримує відкрите обговорення досить довго і по-людськи, для того, щоб сформувати мережу особистих відношень у кіберпросторі. [4, с. 8]. У середині спільноти обмін знаннями і досвідом здійснюється на основі електронної розсилки 
повідомлень, списку новин, дошки оголошень або віртуальних сайтів тощо. Усі заохочення взаємодії, іноді фокусуються навколо особливого інтересу, а іноді i просто спілкуванні.

Віртуальна спільнота - це сукупність індивідів, об'єднаних спільними інтересами, цілями та звичаями, тривала взаємодія яких повністю або, у крайньому випадку, частково здійснюється засобами Інтернету і регулюється специфічними для нього засобами комунікації протоколами і нормами [6] .

У середині спільноти обмін знаннями і досвідом здійснюється у вигляді обміну професійними даними і відомостями.

Віртуальна предметна спільнота - це об’єднання вчителів-предметників, яке виростає з мережі, має спільні інтереси, прагнення та цілі, активно спілкується між собою як на професійні, так і на непрофесійні теми.

У співробітництві 3 Національною академією педагогічних наук України компанією «Майкрософт Україна» було започатковано мережу «Партнерство в навчанні» [3], яка надає більше можливостей освітянам дізнатися про новітні IКТ 3 метою покращання якості навчання. Призначення мережі - створювати професійні віртуальні спільноти, спільно працювати над розробкою уроків, навчальних i методичних матеріалів, обмінюватися досвідом й ідеями, про що зазначає І. Д. Малицька [7].

Розвиток й інтегрування IКТ у системах освіти зарубіжних країн і України є одним із пріоритетних напрямів, тому в мережі «Партнерство в навчанні» було започатковано шість предметних спільнот природничо-математичного циклу:

- математика (ua.partnersinlearningnetwork.com/communities/mathematics);

- фозика (ua.partnersinlearningnetwork.com/communities/geography);

- хімія (ua.partnersinlearningnetwork.com/communities/chemistry);

- біологія (ua.partnersinlearningnetwork.com/communities/biology_b);

- географія (ua.partnersinlearningnetwork.com/communities/geography);

- інформатика (ua.partnersinlearningnetwork.com/communities/informatic).

Метою створення предметних спільнот були: стійкий інноваційний розвиток i навчально-методичне забезпечення природничо-математичної освіти.

Мета створення предметних спільнот: стійкий інноваційний розвиток i навчально-методичне забезпечення природничо-математичної освіти. 
Для досягнення мети сформульовано завдання:

- визначити характерні особливості віртуальної предметної спільноти;

- розробити структуру предметної спільноти;

• залучити вчителів-предметників до колаборації у спільноті;

- наповнити спільноти інформаційно-методичними, дидактичними та розвивальними матеріали з предметів природничо-математичного циклу;

- $\quad$ провести аналіз функціонування віртуальних предметних спільнот. Характерні особливості віртуальної предметної спільноти:

- $\quad$ відсутність бар’єрів комунікації як психологічних, так і географічних;

- інтерактивний характер взаємодії членів, які можуть ефективно обмінюватися корисною і цікавою інформацією;

• можливість самопрезентації і самореалізації вчителів-предметників;

• неформальна структура он-лайн спілкування;

- структурований банк навчально-методичних матеріалів.

Повідомлення, які розміщуються у спільноті можна розділити на п’ять основних груп.

- Статичні з постійною адресою. До цієї групи відносяться різноманітні мережеві публікації. Наприклад, статті, книги, фото тощо.

- Динамічні без постійної адреси. Ця група формується на засадах дискусії, діалогу, обміну думками. Наприклад, електронна пошта, списки розсилання, форуми, чати.

- Динамічні з постійною адресою. Прикладами можуть слугувати блоги, wiki-wiki.

- Інтерактивні з постійною адресою. До цієї групи відносяться різноманітні мережеві публікації (статті, книги, нормативні документи, розробки уроків, презентації, фото тощо), які формуються на засадах інтенсивного колективного використання, обговорення та поліпшення.

- Он-лайн без постійної адреси. Ця група формується на засадах дискусії, діалогу, презентації, обміну думками в режимі реального часу. Наприклад, Adobe Acrobat Connect; COMDI; Dimdim; BigBlueButton, WiZiQ, V-class.ru, Glance Networks (англ.); IBM Lotus Sametime; InterCall (англ.); Microsoft Office Live Meeting; WebEx (англ.); WebTrain (англ.) тощо [2]. 
Структура предметної спільноти включає наступні компоненти: оголошення, дискусії, події, посилання, спільні документи.

Оголошення - для координації діяльності в середині спільноти.

Дискусії - он-лайн обговорення питань, які вимагають обговорення у спільноті.

Події - друкуються повідомлення про події (семінари, конференції, видатні дати, переможці конкурсів тощо), які зацікавлять членів предметної спільноти.

Посилання - підбірка посилать на цікаві сайти, зарубіжні освітні портали, оповіді про використання новітніх технологій у світі, сайти вчителів-новаторів як України, так і зарубіжних країн.

До спільних документів включено: відеоматеріали, презентації уроків, розробки уроків, фотоматеріали та методичне забезпечення.

До відеоматеріалів відносяться відеозаписи дослідів, хімічних, фізичних або біологічних процесів. Роль відеоматеріалів у навчальному процесі не можна переоцінити. Вони унаочнюють ті процеси, які в природі є довготривалими або неможливо побачити без мікроскопа (телескопа).

Презентації - це логічна викладка теоретичного навчального матеріалу, яка за необхідності доповнюється фотоматеріалами, схемами, діаграмами.

Роль презентацій у навчальному процесі - вивчення нового або узагальнення навчального матеріалу, відпрацювання навичок побудови, розв’язання прикладів i задач, тестування, використання як вчителями, так і учнями.

Розробка уроків - конспекти уроків, плани уроків, плани проектів. Такий банк уроків допоможе кожному вчителеві знайти необхідні матеріали, структури уроків, різні педагогічні рішення, ідеї, методичні підходи тощо.

Фотоматеріали - тематична збірка фотографій до розроблених уроків.

Методичне забезпечення - нормативні i методичні матеріали для продуктивної роботи вчителя. Вони у будь-яку хвилину і будь-якому місці «під рукою».

Залучення вчителів до предметних спільнот здійснено за такими напрямками:

- електронне розсилання посилань 3 адресою предметних спільнот на електронні скриньки загальноосвітніх навчальних закладів;

• проведення он-лайн навчальних семінарів для вчителів-предметників; 
- презентація предметних спільнот на науково-практичних семінарах i конференціях.

Учасниками віртуальної предметної спільноти можуть бути координатор (обов’язково), учасники (учителі, учні, батьки), системний адміністратор мережі (здійснює координацію чи допомогу за потребою спільноти).

Права координатора: має власний «nickname», створення/видалення спільноти, видалення членів спільноти, додавання/видалення навчально-методичних матеріалів усіх учасників спільноти, розсилання повідомлень членам спільноти, друкування оголошень, подій, посилань.

Права учасника: має власний «nickname», додавання/видалення власних навчально-методичних матеріалів, розсилання повідомлень членам спільноти, друкування оголошень, подій, посилань.

Розглянемо види віртуальних предметних спільнот.

- Стабільна. Спільнота 3 періодичним наповнюванням навчальнометодичними матеріалами без надміру активних членів спільноти.

- Популярна. Спільнота із систематичним наповнюванням навчальнометодичними матеріалами і збільшенням кількості активних членів спільноти шляхом високої популярності.

- $\quad$ Активна. Спільнота - форум, метою якої є отримання відгуків чи реакції на ту чи іншу подію або отримання миттєвої консультації 3 нагальних питань діяльності вчителя-предметника.

- Б База знань. У сховищах спільноти накопичується якісна інформація 3 певного предмету.

Кожна мережа має свої особливості, які впливають на функціонування i життєздатність віртуальних спільнот, що базуються на ній. Розглянемо особливості формування віртуальних предметних спільнот мережі «Партнерство у навчанні».

1. Відсутність відомостей про події, які відбуваються в предметній спільноті у момент, коли вчитель-предметник не в он-лайні. Він відвідує спільноту за потребою, це можуть бути такі варіанти:

- розміщення у сховищах навчально-методичних матеріалів тривалого «життя»;

- маркування нових матеріалів; 
- зберігання авторства власника матеріалів;

- пошук у сховищах необхідної презентації, відео або нормативного документа;

- участь у дискусії;

- пошук потрібного члена спільноти і зв'язок з ним;

- пошук або відвідування сайтів за посиланнями, розміщеними у спільноті;

- перегляд оголошень спільноти;

- перегляд оголошень і новин мережі тощо.

2. Нечітке структурування навчальних i методичних матеріалів у віртуальних сховищах спільноти:

- сховища спільноти створені за принципом стеку - усе, що додається, розташовується «над»;

- доступні два види сортування матеріалів за алфавітом і за датою;

- у відповідних сховищах відсутній пошук за назвою або ключовим словом, що є досить незручним для вчителя;

- під час пошуку необхідних матеріалів доводиться переглядати сховище від першого до останнього документа.

3. Відсутність єдиного принципу маркування документів. Усі члени віртуальної предметної спільноти називають навчально-методичні матеріали, як їм зручно для роботи, що допускає можливість заміщувати документи інших вчителів без додаткових попереджень системи. Навіть введення додаткового цифрового маркера не дає можливості визначити потрібний документ без обов'язкового його перегляду.

4. Відсутність режиму чату, що унеможливлює живе спілкування або дискусію між учасниками спільноти. Розробники мережі «Партнерство у навчанні» створили можливість відправлення повідомлення члену предметної спільноти, що $\epsilon$ аналогом електронної пошти.

Важливими $є$ і фактори вибору предметної спільноти.

1. К Контент (content) - будь-який електронний документ (документи, вебсайти, презентації, відеозаписи, аудіозаписи). Можливість зберігати в одному місці різнопланові документи які забезпечують діяльність вчителя. Контент поділяється на два основних види: 
- динамічний, який може змінюватися у процесі використання,

- с статичний, який залишається незмінним.

2. Cniвпраця (Collaboration) - забезпечує незалежну від часу та місця взаємодію засобами ІКТ.

Різні підходи підтримують групову роботу і комунікацію у спільноті:

- пряма комунікація підтримується засобами чату, форуму, миттєвих повідомлень, дошок оголошень, відеоконференцій, вебінарів, віртуальних класів;

- підтримка комунікації засобами роботи над спільними проектами;

- підтримка управління засобами наповнення сховищ предметних спільнот нормативно-методичними документами;

- підтримка співпраці у спільноті головне завдання найефективнішого виду колаборації.

3. Узгодженість (Compliance) - слугує одним із факторів життєдіяльності предметної спільноти. Виконання завдань, які стоять перед предметною спільнотою, вимог щодо документів, умов зберігання i використання, адміністрування i розповсюдження, обмін найактуальнішими відомостями залишається життєво необхідною для їі існування.

4. Необмеженість (unboundedness) - фактор вибору мережі як дієвого інструмента в діяльності вчителя-предметника. Зберігання необмеженої кількості навчального матеріалу, нормативних документів, посилань на цікаві сайти в одному сховищі, спілкування 3 колегами як $з$ України, так і 3 усього світу $є$ одним 3 пріоритетних факторів використання предметної спільноти.

Зупинимося на основних підходах колаборації над документами. Існують різні програми, які дозволяють використовувати цілий спектр способів колаборації над документами чи то редагування електронної таблиці, чи отримання дієвої допомоги колеги у розробці проекту, чи залучення учнів до його реалізації тощо. Мережа «Партнерство у навчанні» не забезпечує прямої колаборації. Учителям доцільно задіювати відомі й ефективні програми. Відповідно до ситуації виокремимо такі підходи.

1. Неформальне редагування документів. Це результат колаборації кількох учасників предметної спільноти, до яких можна віднести плани роботи, записи 
мозкового штурму (OneNote, Web Apps), розрахунки витрат на реалізацію проекту, прийом учнів і колег з інших областей України для участі в конкурсі проектів (Excel) тощо. OneNote програмний засіб для запису ідей i думок в одному записничку. Записничок можна вважати віртуальною дошкою. Як за звичайного мозкового штурму не потрібно зразу ж виправляти або оцінювати ідеї. Головне - виразити потік думок. Усі учасники можуть вносити ідеї одночасно, тому є можливість спостерігати за ідеями, які були внесені іншими. Після завершення колаборації залишається запис сеансу, який можна переглянути в довільний час. Кожний фрагмент відмічено nickname автора, який його запропонував. Web Apps допомагає в розв'язуванні аналітичних задач і надає можливість колаборації 3 іншими учасниками. Кілька вчителів можуть одночасно працювати над різними сторінками документа i редагувати один і той же фрагмент. Якщо кілька вчителів змінюють один і той же фрагмент, то зберігається остання правка.

2. Формальне редагування документів. Це узгодження прес-релізів, договорів закупівлі, завдань на олімпіаду, положень про конкурси, вимог до проведення електронного уроку (Word), а також презентації досвіду, виступи на конференціях (PowerPoint) тощо. Особливістю використання даних програм є те, що за необхідності завжди можна дізнатися, що змінено в документі іншими учасниками предметної спільноти. Таке редагування передбачає, що всім відомо, над чим працюють інші вчителі, але кожний з них друкує або зберігає у сховищі тільки готові або затверджені зміни. Якщо на комп’ютері встановити програмний засіб Microsoft Lync, то створюються умови для колаборації у реальному часі. Учителям можна відправити миттєве повідомлення, повідомлення електронною поштою, зателефонувати тощо.

3. Рецензування документів. Це внесення правок і доповнень у рамках робочого моменту.

Отже, віртуальні предметні спільноти мають певні особливості функціонування, які впливають як на їі документообіг, колаборацію всередині спільноти, вибір тієї чи іншої спільноти вчителями, так і на їі існування i життєздатність.

Аналіз діяльності віртуальних предметних спільнот потребує подальших досліджень і визначення критеріїв оцінювання наповнюваності предметних сховищ. 
Наповнення нормативно-методичних сховищ спільнот здійснено вчителямипредметниками, координаторами спільнот та методистами. Нормативно-методичні документи регламентують діяльність вчителя і включають інструкції (з техніки безпеки, протипожежної безпеки, безпека під час проведення екскурсій, лабораторних робіт тощо), навчальні плани, методичні рекомендації (щодо викладання предметів, проведення Всеукраїнських олімпіад), листи МОНмолодьспорт України, листи місцевих органів управління (ГУОН м. Києва, обласні управління освіти тощо), листи інститутів підвищення кваліфікації (графіки проходження курсів підвищення кваліфікації) тощо.

Отже, створення й наповнення інформаційних сховищ віртуальних предметних спільнот слугує засобом управління нормативно-методичним забезпеченням діяльності вчителя-предметника загальноосвітнього навчального закладу.

Аналіз діяльності віртуальних предметних спільнот потребує визначення основних критеріїв оцінювання і можливостей додаткової підтримки функціонування.

\section{Список використаних джерел}

1. Вікіпедія: вільна енциклопедія [Електронний ресурс]. - Режим доступу : http://uk.wikipedia.org/. - Заголовок з екрана.

2. Литвинова C. $Г$. Віртуальний клас як комп'ютерно орієнтоване навчальне середовище вчителя загальноосвітнього навчального закладу [Електронний ресурс] / Світлана Григорівна Литвинова // Інформаційні технології і засоби навчання. - 2011. - № 2(22). - Режим доступу : http://journal.iitta.gov.ua/index.php/itlt/article/view/331/387. - Назва з екрана.

3. Мережа Партнерство в навчанні [Електронний ресурс]. - Режим доступу : http://ua.partnersinlearningnetwork.com. - Заголовок з екрана.

4. Патаракин Е. Д. Сетевые сообщества и обучение, / Е. Д. Патаракин. - М. : «ПЕР СЭ», 2006 . - $112 \mathrm{c}$.

5. Про схвалення Концепції Державної цільової соціальної програми підвищення якості шкільної природничо-математичної освіти на період до 2015 року [Електронний ресурс]. - Режим доступу : http://zakon.rada.gov.ua/cgibin/laws/main.cgi?nreg=1720-2010-\%F0. - Заголовок з екрана. 
6. Чураева H. Социально-психологические механизмы формирования виртуальных сообществ : дис. ... канд. психол. наук : спец. 19.00.05 / Н. С. Чураева. M., 2009. - 201 c.

7. Малицька I. Д. Глобальні освітні мережі та їх комунікативний потенціал (зарубіжний досвід) [Електронний ресурс] / І. Д. Малицька // Інформаційні технології і засоби навчання. - 2011. - № 3(23). - Режим доступу : http://www.nbuv.gov.ua/ejournals/ITZN/2011_3/11midpzd.pdf. - Назва з екрана.

8. Dennis Altman. Power and Community. Organiztaionnal and Cultural Responses to AIDS, Taylor \& Francis, London, 1994.

\section{ВИРТУАЛЬНЫЕ ПРЕДМЕТНЫЕ СООБЩЕСТВА КАК СРЕДСТВО ПОДДЕРЖКИ ЕСТЕСТВЕННО-МАТЕМАТИЧЕСКОГО ОБРАЗОВАНИЯ}

Литвинова Светлана Григорьевна, младший научный сотрудник Института информационных технологий и средств обучения НАПН Украины, г. Киев, e-mail: s_litvinova@i.ua

\section{Аннотация}

Статья посвящена поиску путей повышения качества школьного естественноматематического образования, которые направлены на использование виртуальных предметных сообществ и реализацию задач, включающих разработку структуры предметных сообществ, привлечение учителей-предметников к сотрудничеству в сообществах, создание информационно-методических, дидактических и развивающих материалов, обеспечение условий их использования в школе, проведение анализа функционирования сообществ.

В статье раскрыты особенности виртуальных предметных сообществ, определены их виды (стабильная, популярная, активная, база знаний), особенности формирования и факторы выбора предметного сообщества учителямипредметниками, определены основные подходы коллаборации над документами (неформальное, формальное изменение и рецензирование документов), особенности привлечения учителей-предметников к сотрудничеству в сообществах.

Ключевые слова: виртуальные сообщества, виртуальные предметные сообщества, естественно-математическое образование, сеть, качество школьного образования. 


\section{VIRTUAL SUBJECT COMMUNITIES AS MEANS OF SUPPORT OF NATURAL MATHEMATICS EDUCATION}

Svitlana G. Lytvynova, junior researcher of the Institute of Information Technologies and Learning Tools of NAPS of Ukraine, Kyiv, e-mail: s_litvinova@i.ua

\section{Resume}

The article is devoted to finding ways to improve the quality of school naturalmathematics education, which focused on the use of virtual subject communities and implementation of tasks involving the development of subject community structure, involving subject teachers to work in the community, creating awareness and learning, teaching and developing materials, providing conditions for their use in schools, analyzing the functioning of the communities.

In the article the features of virtual subject communities are identified by their types (stable, popular, active, knowledge base), it is determined the basic approaches of collaboration with documents (informal, formal change and document review) as well as particularly involvement of subject teachers to work in the community.

Keywords: virtual communities, virtual subject community, natural-mathematics education, network, quality of school education. 